\title{
Alveolar Macrophage Status in Bronchopulmonary Dysplasia
}

\author{
A. CLEMENT, K. CHADELAT, A. SARDET, A. GRIMFELD, AND G. TOURNIER \\ Pulmonary Department of Pediatrics, Hopital Trousseau, Paris, France
}

\begin{abstract}
The predominant inflammatory cell type within the alveolar structure in bronchopulmonary dysplasia (BPD) is the alveolar macrophage (AM). AM ability to release hydrogen peroxide, a way to evaluate the cell status, was studied in nine infants who developed clinical and radiological evidence of BPD, and was compared to those from infants without lung parenchymal disorders ( $n$ $=6$ ). AM were collected by bronchoalveolar lavage which was done after the mechanical ventilation stage in the BPD group. The experiments were performed on unstimulated $\mathrm{AM}$ and on AM stimulated by phorbol myristate acetate. Results revealed that the amount of hydrogen peroxide accumulated in the culture medium was significantly enhanced in the BPD group, in both experimental conditions ( $p<0.01$ and $<0.001$, respectively). Furthermore, improvement of patients treated with glucocorticoids was closely related to a reduction of the alveolitis with a decrease of AM ability to generate hydrogen peroxide. These data indicate that AM activation is a central component of alveolitis in BPD and that extracellular production of oxidants by stimulated AM may play a critical role in the pathogenesis of the disease. (Pediatr Res 23: 470-473, 1988)
\end{abstract}

Abbreviations

AM, alveolar macrophage

BPD, bronchopulmonary dysplasia

RDS, respiratory distress syndrome

$\mathrm{H}_{2} \mathrm{O}_{2}$, hydrogen peroxide

PMA, phorbol myristate acetate

L, lymphocyte

PMN, polymorphonuclear

FRC, functional residual capacity

CLdyn, dynamic lung compliance

$\mathrm{RL}$, total pulmonary resistance

PRS, phenol red assay solution

HRP, horseradish peroxidase

BAL, bronchoalveolar lavage

$\mathrm{FiO}_{2}$, fractional inspired oxygen

PRS, phenol red assay solution

According to numerous studies on the pathology of BPD, diffuse alveolar damage appears to be an early event in the development of this chronic lung disease, and histological descriptions have revealed a chronological progression from an

Received August 5, 1986; accepted January 6, 1988

Correspondence A. Clement, Departement de Pneumologie Pediatrique, Hopital Trousseau, 28, Av Dr Netter. 75012 Paris, France.

Supported by Grant 85 MRS from Les Comites Francais Departementaux Contre les Maladies Respiratoires et la Tuberculose, and by a grant from Le Conseil Scientifique de l'EVR St. Antoine. initial exudative stage of the alveolar lesion to a regenerative stage with repair (1-3). Furthermore, recent observations support the view that parenchymal inflammation could play a definite role in the development of $\mathrm{BPD}(4,5)$.

The predominant inflammatory cell type within the alveolus is the AM that functions not only as a phagocytic cell but also as a secretory cell $(6,7)$. Among the numerous secretory products of AM that modulate the inflammatory and immune responses are the reactive $\mathrm{O}_{2}$ metabolites. Generation of these species is associated with an increase in $\mathrm{O}_{2}$ consumption and glucose catabolism via the hexose monophosphate shunt. These reactions are referred to as "the respiratory burst," and can be induced by a wide variety of stimuli $(6-11)$. Furthermore, it has become increasingly apparent that $\mathrm{AM}$ can function as an initiator of the inflammatory response and can use "defense-like mechanisms" to contribute to lung injury. During these processes that lead to lung damage, the increased amount of $\mathrm{O}_{2}$ metabolites production by AM is associated with a change of the cell status and is related to the concept of macrophage activation $(12,13)$.

AM can be collected by BAL. This procedure has proved to be safe and well tolerated in infants and children, and therefore appears to be an efficient and powerful technique for the study of pulmonary conditions in pediatrics (14). Using this new method of investigation, our study was undertaken with two objectives: 1) to investigate the capacity of AM from BPD patients to generate $\mathrm{O}_{2}$ metabolites and therefore to evaluate the activity of cells that might contribute to lung damage; and 2) to determine whether glucocorticoids influence AM activation and therefore the inflammatory alveolar process of this chronic lung disease.

\section{MATERIALS AND METHODS}

Patients. Nine infants who developed BPD were enrolled in this study. Criteria for patients selection were as follows: 1) they had been admitted in a neonatal intensive care unit and had assisted ventilation for RDS; RDS was diagnosed on the basis of cyanosis, retraction, respiratory grunting, and radiographic findings of a reticular granular pattern and air bronchograms; 2) they developed severe BPD. The diagnosis of BPD was made as infants fulfilled all of the following criteria (15): required intermittent positive pressure ventilation during the first week of life and for a minimum of 3 days, required supplemental oxygen for more than 28 days, and developed chest $x$-ray changes consistent with the diagnosis of BPD. The records of these infants were evaluated for birth weight, gestational age, duration of mechanical ventilation, and duration of $\mathrm{FiO}_{2}>0.4$ (Table 1). At the time of scheduled BAL, each infant had physical and radiological evaluations, and arterialized capillary blood gases determination during air breathing (16). The pulmonary function tests performed in five patients included measurements of FRC using a spirographic system adapted to the age of the children, and of CLdyn and RL by using the esophageal balloon technique (17). CLdyn and RL were calculated on the basis of 10 successive 
Table 1. Characteristics of infants with BPD

\begin{tabular}{|c|c|c|c|c|c|c|c|c|c|}
\hline Patient & 1 & 2 & 3 & 4 & 5 & 6 & 7 & 8 & 9 \\
\hline Birth wt (g) & 1000 & 2800 & 1200 & 3410 & 2150 & 2100 & 1930 & 1130 & 995 \\
\hline Gestational age (wk) & 31 & 35 & 28 & 39 & 37 & 33 & 34 & 29 & 28 \\
\hline Ventilation duration (days) & 8 & 120 & 106 & 7 & 38 & 39 & 101 & 87 & 53 \\
\hline $\mathrm{FiO}_{2} 0.4$ (days) & 2 & 60 & 57 & 4 & 10 & 13 & 85 & 48 & 39 \\
\hline \multicolumn{10}{|l|}{ At the time of the initial study } \\
\hline Age (mo) & 5 & 5 & 4 & 2 & 3 & 3 & 5 & 4 & 4 \\
\hline Body wt (kg) & 3.4 & 5.5 & 4.4 & 3.9 & 3.5 & 3.5 & 4.6 & 3.2 & 3.7 \\
\hline $\mathrm{PaO}_{2}(\mathrm{~mm} \mathrm{Hg})$ & 44 & 60 & 55 & 58 & 55 & 47 & 49 & 42 & 50 \\
\hline $\mathrm{PaCO}_{2}(\mathrm{~mm} \mathrm{Hg})$ & 57 & 42 & 48 & 42 & 45 & 43 & 46 & 48 & 50 \\
\hline
\end{tabular}

breaths at resting and expiratory level and resting respiratory frequency. FRC and mechanical parameters were expressed as percent of predicted values.

The control group included six infants without neonatal respiratory disorders. In this group, BAL was performed during screening endoscopy in an evaluation of stridor. None had an history of acute lung disease during the 4 wk preceding the BAL. At the time of the study, the mean age of the group was 6 months $( \pm 1$ month); and all these infants had normal physical development, chest radiograph, and arterial blood gases.

Technique and treatment of $B A L$. Written informed consent was obtained from the parents of each infant. The study was approved by the Human Experimentation Committee of St. Antoine University Hospital of Paris. The BAL was done during bronchoscopy under local anesthesia (14). The bronchoscope was introduced into a lower right lobe segment. The volume of normal saline $(0.15 \mathrm{~N} \mathrm{NaCl})$ used was equivalent to $10 \%$ of the predicted FRC. The sterile solution was injected in six aliquots. Only the last five aliquots of aspiration fluids were collected. One sample of the recovered BAL fluid was used for microbiological and cytological studies including total cell count and differential cell count after a cytocentrifuge preparation.

$A M$ isolation. AM were isolated by differential adherence (18). The BAL cells were collected by centrifugation at $400 \times g$ for 10 min at $4^{\circ} \mathrm{C}$. The cells were then washed once with RPMI 1640 medium containing $30 \mathrm{mM} \mathrm{NaHCO} 3$ and $25 \mathrm{mM}$ HEPES neutralized to $\mathrm{pH}$ 7.4. Medium was supplemented with $50 \mathrm{U}$ penicillin $\mathrm{G}$ and $50 \mu \mathrm{g}$ streptomycin per $\mathrm{ml}$ of medium. The washed cells were suspended at a concentration of $3-5.10^{5}$ cells $/ \mathrm{ml}$ in RPMI medium and added to $35-\mathrm{mm}$ Petri dishes (Falcon, Oxnard, CA). The dishes were incubated at $37^{\circ} \mathrm{C}$ in $5 \% \mathrm{CO}_{2}$ to allow adherence of macrophages. After $2 \mathrm{~h}$ of incubation, the nonadherent cells were discarded and the monolayer, which was more than $95 \%$ macrophages as determined by differential staining, was washed with Hanks' balanced salt solution.

Assay for $\mathrm{H}_{2} \mathrm{O}_{2}$ production. Production of $\mathrm{H}_{2} \mathrm{O}_{2}$ by $\mathrm{AM}$ was measured using the method described by Pick and Keisari (19), based on the $\mathrm{H}_{2} \mathrm{O}_{2}$-mediated and HRP-dependent oxidation of phenol red. The PRS contained $140 \mathrm{mM} \mathrm{NaCl}, 10 \mathrm{mM}$ potassium phosphate buffer, $\mathrm{pH} 7.0,5.5 \mathrm{mM}$ dextrose, $0.28 \mathrm{mM}$ phenol red, and $8.5 \mathrm{U} / \mathrm{ml}$ HRP. The adherent cells were covered with $1 \mathrm{ml}$ of PRS prewarmed to $37^{\circ} \mathrm{C}$. AM were stimulated by the addition of $5 \mu \mathrm{g} / \mathrm{ml}$ of PMA in some experimental conditions, and the dishes were incubated for $30 \mathrm{~min}$ at $37^{\circ} \mathrm{C}$. At the end of the incubation, the culture fluids were collected and centrifuged. The cell-free supernatants were made alkaline by the addition of $10 \mu \mathrm{l} 1 \mathrm{~N} \mathrm{NaOH}$; the absorbance was determined at $610 \mathrm{~nm}$ against a blank of PRS to which $10 \mu \mathrm{l}$ of $1 \mathrm{~N} \mathrm{NaOH}$ was added (Perkin Elmer Corp., Pomona, CA, Lambda 1 spectrophotometer C 632.0001). Standard curves were made, using the same preparation of PRS, with $1-30 \mu \mathrm{M} \mathrm{H}_{2} \mathrm{O}_{2}$ solutions. The standards were treated in the same manner as the experimental cultures. In some instances, $1250 \mathrm{U} / \mathrm{ml}$ catalase was used specifically to inhibit $\mathrm{H}_{2} \mathrm{O}_{2}$ accumulation. The amount of $\mathrm{H}_{2} \mathrm{O}_{2}$ produced was calculated from the standard curve. The cells were scraped in $0.8 \mathrm{~N} \mathrm{NaOH}$ for protein determination according to the method of Lowry et al. (20). The results were expressed as nmol of $\mathrm{H}_{2} \mathrm{O}_{2}$ generated per $\mathrm{mg}$ cell protein.
Reagents and media. PMA, Phenol red, HPR (type II salt free power), and catalase (bovine liver, 11,000 U/mg) were purchased from Sigma Chemical Co. St. Louis, MO. RPMI 1640 was obtained from GIBCO, Grand Island, NY. PMA was dissolved in dimethylsulfoxide at $5 \mathrm{mg} / \mathrm{ml}$, aliquoted, and stored at $-70^{\circ}$ C.

Data analysis. Data are expressed as mean values \pm SEM. Statistical significance was evaluated by unpaired $t$ tests.

\section{RESULTS}

$B P D$ patients. At the time of the study, the age of the infants ranged from 2 to 5 months (mean age 4 months). They were free of infectious disease but clinical signs of respiratory distress, mainly tachypnea, were present. The chest radiographs showed severe BPD, characterized by areas of cystic radiolucency alternating with strands of radiodensity. Arterialized capillary blood gases showed that $\mathrm{PaO}_{2}$ was decreased to values outside the normal range (mean \pm SEM $52 \pm 2 \mathrm{~mm} \mathrm{Hg}$ ). All the patients had supplemental $\mathrm{O}_{2}$ therapy when the BAL was scheduled. The pulmonary functions tests performed in five patients (nos. 2, 4, $7,8,9$ ) indicated that FRC was not significantly different from the predicted values. In all infants, CLdyn was less than -2 SD from the regression line on the diagram of predicted values of $-57,-65,-55,-57$, and $-44 \%$, respectively, and RL was significantly increased (more than +2 SD from the regression line $)$ in each case $(+281,+283,+72,+175$, and $+268 \%$, respectively).

Characteristics of BAL fluids. The recovery of lavage fluid ranged between $60-70 \%$ and did not correlate with the status of the infants at the time of the study. The cytological studies were reported in Table 2 . The total number of cells $/ \mathrm{ml}$ was significantly increased in the BPD group, $p<0.05$. No marked differences in the percentages of AM, L, and PMN were apparent between the two groups. In each case, the microbiological studies of lavage fluid were negative.

$\mathrm{O}_{2}$ metabolites release by $A M$. These experiments were done on unstimulated and stimulated AM after a $2 \mathrm{~h}$ culture duration in medium without serum. In previous studies performed in our laboratory, we have indicated that the amount of $\mathrm{O}_{2}$ metabolites release by unstimulated and stimulated AM was linear with time up to $90 \mathrm{~min}$. We have also reported that for PMA stimulation, a plateau was reached at a concentration of $5 \mu \mathrm{g} / \mathrm{ml}(21)$. Herein, $\mathrm{H}_{2} \mathrm{O}_{2}$ accumulation in the medium was measured after a $30-\mathrm{min}$ incubation period, and the experimental protocol included nonstimulated AM and AM stimulated by $5 \mu \mathrm{g} / \mathrm{ml}$ PMA.

The results of the experiments are reported in Figure 1. The ability of AM to generate $\mathrm{O}_{2}$ metabolites was greatly enhanced in the BPD group. A statistically significant increase of $\mathrm{H}_{2} \mathrm{O}_{2}$ release per mg cell protein was observed in the BPD group for both unstimulated AM and PMA-stimulated AM (control group versus BPD group, mean \pm SEM), protein amount per Petri dish: $98 \pm 15 \mathrm{mg}$ versus $104 \pm 17 \mathrm{mg} ; \mathrm{H}_{2} \mathrm{O}_{2}$ release by unstimulated AM: $10.8 \pm 2.1$ versus $19.6 \pm 1.7 \mathrm{nmol} / \mathrm{mg}$ protein $/ 30 \mathrm{~min}, p$ $<0.01 ; \mathrm{H}_{2} \mathrm{O}_{2}$ release by PMA-stimulated AM: $24.6 \pm 1.8$ versus $62.4 \pm 4.4 \mathrm{nmol} / \mathrm{mg}$ protein $/ 30 \mathrm{~min}, p<0.001$. The addition of catalase $(1250 \mathrm{U} / \mathrm{ml})$ to cultures of macrophages in PRS 
without stimulant or in the presence of PMA completely abolished $\mathrm{H}_{2} \mathrm{O}_{2}$ generation.

Based on these results and supported by data from other studies, an antiinflammatory treatment was then proposed. As some parents were reluctant to give consent, prednisone treatment was given to five children (nos. $2,3,7,8,9$ ). The therapeutic protocol was the following: 1) $2 \mathrm{mg} / \mathrm{kg} /$ day of prednisone for 1 month and then a progressive decrease; 2) a clinical, functional, and BAL evaluation 2 months after the onset of the treatment. No complications were reported. Clinical improvement in the treated group was assessed by physical examination that showed that respiratory frequency was markedly decreased. Results of functional and BAL studies after prednisone treatment are indicated in Table 3. In each case hypoxemia was corrected and CLdyn improved and was within the normal range in two infants. The results of BAL cytological studies in this treated group indicated that the total cell number $/ \mathrm{ml}$ was significantly de-

Table 2. Cytological characteristics of BAL (mean \pm SEM)

\begin{tabular}{ccccc}
\hline Group & $\begin{array}{c}\text { Cell count } \\
\left(10^{3} / \mathrm{mI}\right)\end{array}$ & $\begin{array}{c}\text { AM } \\
(\%)\end{array}$ & $\begin{array}{c}\text { L } \\
(\%)\end{array}$ & \multicolumn{1}{c}{$\begin{array}{c}\text { PMN } \\
(\%)\end{array}$} \\
\hline Control & 295 & 90.9 & 7.8 & 1.3 \\
& \pm 68 & \pm 2.1 & \pm 1.8 & \pm 0.5 \\
BPD & 791 & 93.1 & 4.7 & 1.9 \\
& \pm 234 & \pm 2.4 & \pm 1.7 & \pm 1.1 \\
\hline
\end{tabular}
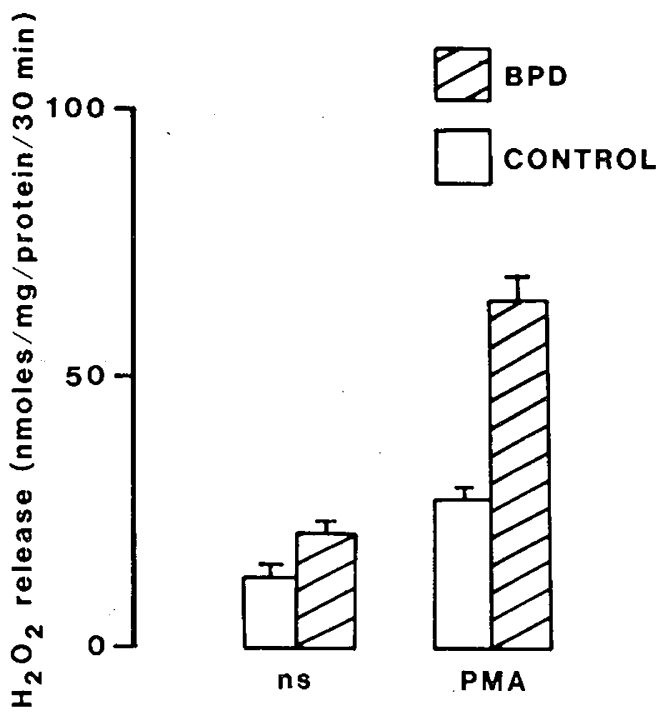

Fig. 1. $\mathrm{H}_{2} \mathrm{O}_{2}$ release by $\mathrm{AM}$ from control infants and from infants with BPD. Experiments were performed on nonstimulated cells $(n s)$ and on PMA-stimulated cells (PMA). Results are expressed as nmol of $\mathrm{H}_{2} \mathrm{O}_{2}$ released per $\mathrm{mg}$ protein per $30 \mathrm{~min}$. The bars represent the mean \pm SEM. creased with no change in the percent of various cells. The measurements of $\mathrm{H}_{2} \mathrm{O}_{2}$ generation by $\mathrm{AM}$ after prednisone showed a decrease of this production both in unstimulated and PMA-stimulated AM. However, at the time of the study, the amount of $\mathrm{H}_{2} \mathrm{O}_{2}$ release after PMA stimulation remained above the range observed in the control group. Further pulmonary function tests and BAL studies were not carried out in infants who received no prednisone. However, 2 months after the pulmonary evaluation, clinical conditions were not markedly changed and they still required $\mathrm{O}_{2}$ therapy.

\section{DISCUSSION}

The pathogenesis of BPD is complex but it is widely believed that oxidant injury plays a critical role in the development of this chronic lung disease $(1,22)$. In BPD, oxidants, such as oxygen metabolites and other free radicals, can be generated from many sources. Extracellular formation may be initiated by stimulated phagocytes such as AM and PMN; excessive intracellular production is induced by hyperoxia $(23,24,33)$.

Recently, considerable attention has been directed to the involvement of oxidants in the inflammatory process $(25,33)$. The pulmonary inflammatory noticed during the course of the neonatal RDS has been investigated by Merrit et al. (5) who reported a predominance of PMN in tracheal aspirates from newborns with RDS at the early stage of the disease, whereas after the first week of life the predominant inflammatory cell type was AM. Recently, Ogden et al. (4), using a modified BAL procedure, showed that significant PMN and AM influxes were present at $96 \mathrm{~h}$ in RDS, and that PMN counts remained significantly elevated after 5 wk in BPD. It is likely that the cell population within the alveolar structure is modified during the course of the disease. Herein BAL was performed after ventilatory therapy and therefore at a later stage than the work reported above. In our population, the main feature of the BAL cytological evaluation was an increase of the total cell count $/ \mathrm{ml}$ in the BPD group, but no differences in the percentage of AM, L, PMN were found when the two groups were compared. These observations support the consideration that at this stage of the disease, the alveolitis in BPD is mainly associated with an influx of AM, and led us to investigate the oxidative metabolism and state of activation of AM.

Herein we report evidence that AM from infants with BPD have a higher capacity to generate $\mathrm{O}_{2}$ metabolites in vitro than those from control subjects. The increased $\mathrm{H}_{2} \mathrm{O}_{2}$ production was demonstrated for both stimulated and unstimulated cells. These results are similar to the data reported in adult inflammatory lung diseases such as sarcoidosis (26) and in children with interstitial lung diseases (21). The mechanisms by which these species may play a role in lung injury have been intensively investigated and many possibilities have been proposed. $\mathrm{O}_{2}$ products can damage cells directly by oxidative attack on cell constituents including protein, lipids, and nucleic acids which could lead to cell death $(24,27)$. Oxidants also trigger other reactions that can

Table 3. Results of steroid therapy

\begin{tabular}{|c|c|c|c|c|c|c|c|c|c|c|}
\hline \multirow[b]{2}{*}{ Patient } & \multicolumn{2}{|c|}{2} & \multicolumn{2}{|c|}{3} & \multicolumn{2}{|c|}{7} & \multicolumn{2}{|c|}{8} & \multicolumn{2}{|c|}{9} \\
\hline & -* & $+*$ & - & + & - & + & - & + & - & + \\
\hline $\mathrm{PaO}_{2}(\mathrm{~mm} \mathrm{Hg})$ & 60 & 69 & 55 & 67 & 49 & 69 & 42 & 71 & 50 & 74 \\
\hline $\mathrm{RL}(\%)$ & +281 & +246 & & & +72 & +108 & +176 & +90 & +268 & +159 \\
\hline ClDyn (\%) & -57 & -18 & & & -55 & -11 & -57 & -27 & -44 & -39 \\
\hline $\begin{array}{l}\text { Total BAL cells }\left(10^{3} /\right. \\
\quad \mathrm{ml})\end{array}$ & 1310 & 450 & 2000 & 160 & 600 & 370 & 440 & 250 & 490 & 250 \\
\hline \multicolumn{11}{|l|}{$\begin{array}{l}\mathrm{H}_{2} \mathrm{O}_{2} \text { generation by } \\
\text { AM } \dagger\end{array}$} \\
\hline Unstimulated & 21.4 & 7.4 & 27.5 & 14.8 & 14.4 & & 17 & 5.4 & 17.5 & 4 \\
\hline PMA stimulated & 46.9 & 11.8 & 62.4 & 42.8 & 67.4 & 36.1 & 80.5 & 36.4 & 65.7 & 39.9 \\
\hline
\end{tabular}

* Data are indicated before steroid treatment $(-)$ and after steroid treatment $(+)$.

$\dagger$ Data are expressed as nmol of $\mathrm{H}_{2} \mathrm{O}_{2} / \mathrm{mg}$ protein after a 30-min incubation period. 
indirectly amplify lung damage. These reactions involve inactivation of antiproteases, production of compounds that recruit and/or stimulate phagocytic cells to release $\mathrm{O}_{2}$ metabolites, and interactions with arachidonic acids that generate cycloxygenase and lipoxygenase products $(24,25)$. The pulmonary damage induced by these factors includes attack of the alveolar cells, alteration of surfactant and formation of atelectasis, pulmonary hypertension and increased capillary permeability, and lung infection due to altered tracheobronchial clearance and AM function $(28,29,33)$.

Our data support the consideration that macrophage activation is an important component of the alveolitis observed in BPD. Based on the results herein and of other investigations, antiinflammatory treatment was started in five patients. Glucocorticoids are used extensively in the management of inflammatory disorders. In addition, it has been shown that in children with interstitial lung disease, the dramatic improvement induced by steroid treatment was associated with a remarkable reduction of the $\mathrm{AM}$ ability to generate $\mathrm{H}_{2} \mathrm{O}_{2}$ in vitro (21). The conclusions that can be drawn from the prednisone therapy in our BPD population are preliminary because this study was not doubleblind and randomized. Nevertheless, the clinical and functional results are interesting. Whereas the untreated patients still required $\mathrm{O}_{2}$, the steroid-treated patients corrected their hypoxemia within 2 months after the start of prednisone. This improvement was closely related to a reduction of the alveolitis assessed by a decrease of the total cell number per $\mathrm{ml}$ in the BAL fluid and a decrease of the ability of AM to generate $\mathrm{H}_{2} \mathrm{O}_{2}$. Several studies using corticosteroid therapy in BPD have been reported with various results, but in most of them the treatment was used in the early stages of the disease, before weaning from the respiratory support $(30,31)$. Herein the patients were investigated after mechanical ventilation was discontinued. When the infants were enrolled, they had severe BPD, and the steroid treatment was proposed based on classical investigations (clinical and functional), and on cytological evidence of active disease. Using these parameters, we have shown a remarkable improvement of the patient status; nevertheless 2 months after the onset of prednisone, some functional components remained abnormal and the alveolitis had not completely regressed. These results are encouraging and require further investigations to evaluate the most appropriate antiinflammatory therapeutic strategy.

In summary, these results support the consideration that alveolitis remains persistent in severe $\mathrm{BPD}$, after the mechanical ventilation stage. The study of BAL cells lead to the conclusion that macrophage activation is a central component of this alveolitis, and that $\mathrm{O}_{2}$ metabolites generation by phagocytic cells is greatly enhanced in BPD. Consequently, these data emphasize the potential involvement of oxidant injury in the pathogenesis of the disease. Based on this consideration, they provide additional interest and support for antiinflammatory treatments that might be most safely used after mechanical ventilation has been discontinued. These data also suggest that new therapeutic strategies with attempts to increase pulmonary antioxidant defenses might be of value in the management of $\operatorname{BPD}(32,33)$.

Acknowledgments. The authors thank Dr. Jerome S. Brody for critical review of the manuscript and Dr. Michele Boule for the pulmonary function tests.

\section{REFERENCES}

1. O'Brodovich HM, Mellins RB 1985 Bronchopulmonary dysplasia. Am Rev Respir Dis 132:694-709

2. Taghizadeh A, Reynolds EDR 1976 Pathogenesis of bronchopulmonary dys- plasia following hyaline membrane disease. Am J Pathol 82:241-258

3. Bonikos DS, Bensh KG, Northway WH, Edwards DK 1976 Bronchopulmonary dysplasia: the pulmonary pathologic sequel of necrotizing bronchiolitis and pulmonary fibrosis. Hum Pathol 7:643-666

4. Ogden BE, Murphy SA, Saunders GC, Pathak D, Johnson JD 1984 Neonatal lung neutrophils and elastase/proteinase inhibitor imbalance. Am Rev Respir Dis 130:817-821

5. Merritt TA, Stuart ID, Puccia J 1981 Cytologic evaluation of pulmonary effluent in neonates with respiratory distress and bronchopulmonary dysplasia. Acta Cytol 25:631-639

6. Fels AO, Cohn ZA 1986 The alveolar macrophage. J Appl Physiol 60:353-369

7. Nathan CF, Murray HW, Cohn ZA 1980 The macrophage as an effector cell. N Engl J Med 303:622-626

8. Babior BM, Kipnes RS, Curnutte JT 1973 Biological defense mechanisms: the production by leucocytes of superoxide, a potential bactericidal agent. J Clin Invest 52:741-744

9. Karnovsky ML, Lazdins JK 1978 Biochemical criteria for activated macrophages. J Immunol 121:809-813

10. Nathan CF 1982 Secretion of oxygen intermediates: role in effector functions of activated macrophages. Fed Proc 41:2206-2211

11. Tsunawaki S, Nathan CF 1985 Enzymatic basis of macrophage activation. J Biol Chem 259:4305-4312

12. Martin WJ, Gadek JE, Hunninghake GW 1981 Oxidant injury of lung parenchymal cells. J Clin Invest 68:1277-1288

13. Cochrane CG, Spragg R, Revak SD 1983 Pathogenesis of the adult respiratory distress syndrome: evidence of oxidant activity in bronchoalveolar fluid. $\mathrm{J}$ Clin Invest 71:754-761

14. Grimfeld A, Garcia J, Sardet A, Bernaudin JF, Le Moing G 1983 Technique et resultats normaux du lavage bronchoalveolaire chez l'enfant sain. Rev Fr Mal Respir 11:332-333

15. Bancalari E, Abdenour GE, Feller R, Gannon J 1979 Bronchopulmonary dysplasia: Clinical presentation. J Pediatr 85:819-823

16. Gaultier Cl, Boule M, Allaire Y, Clement A, Buvry A, Girard F 1978 Determination of capillary oxygen tension in infants and children. Assessment of methodology and normal values during growth. Bull Eur Physiopathol Respir 14:287-297

17. Gaultier Cl, Chaussain M, Boule M. Buvry A, Allaire Y, Perret L, Girard F 1980 Lung function in interstitial lung diseases in children. Bull Eur Physiopathol Respir 16:57-66

18. Johnston RB, Godzik CA, Cohn ZA 1978 Increased superoxide anion production by immunologically activated and chemically elicited macrophages. $\mathbf{J}$ Exp Med 148:115-127

19. Pick E, Keisari Y 1980 A simple colorimetric method for the measurement of hydrogen peroxide produced by cells in culture. J Immunol Methods 38:161170

20. Lowry $\mathrm{OH}$, Rosebrough NJ, Farr AL 1951 Protein measurement with the Folin phenol reagent. J Biol Chem 193:265-275

21. Clement A, Chadelat K, Masliah J, Housset B, Sardet A, Grimfeld A, Tournier $\mathrm{G} 1987$ A controlled study of $\mathrm{O}_{2}$ metabolites release by alveolar macrophages from children with interstitial lung disease. Am Rev Respir Dis $136: 1424-1428$

22. Goetzman BW 1986 Understanding bronchopulmonary dysplasia. AJDC 140:332-334

23. Turrens JF, Freeman BA, Crapo JD 1982 Hyperoxia increases $\mathrm{H} 2 \mathrm{O} 2$ release by lung mitochondria and microsomes. Arch Biochem Biophys 217:411421

24. Jackson RM 1985 Pulmonary oxygen toxicity. Chest 88:900-905

25. Fischer AB, Forman HJ, Glass M 1984 Mechanisms of pulmonary oxygen toxicity. Lung 162:255-259

26. Fels AO, Nathan CF, Cohn ZA 1987 Hydrogen peroxide release by alveolar macrophages from sarcoid patients and by alveolar macrophages from normals after exposure to recombinant interferons $\alpha \mathrm{A}, \beta$ and $\gamma$ and 1,25dihydroxyvitamin $\mathrm{D}_{3}$. J Clin Invest 80:381-386

27. Clement A, Hubscher U, Junod AF 1985 Effects of hyperoxia on DNA synthesis in cultured porcine aortic endothelial cells. J Appl Physiol 59:11101116

28. Fox RB, Hoidal JR, Brown OM, Repine JE 1981 Pulmonary inflammation due to oxygen toxicity: involvement of chemotactic factors and polymorphonuclear leukocytes. Am Rev Respir Dis 123:521-523

29. Ward JA, Roberts RJ 1984 Effect of hyperoxia on phosphatidyl choline synthesis, secretion, uptake and stability in the newborn rabbit lung. Biochem Biophys Acta 796:42-50

30. Mammel MC, Green TP, Johnson DE, Thompson TR 1983 Controlled trial of dexamethasone therapy in infants with bronchopulmonary dysplasia. Lancet 2:1356-1357

31. Avery GB, Fletcher AB, Kaplan M, Brudno DS 1985 Controlled trial of dexamethasone in respirator-dependency infants with bronchopulmonary dysplasia. Pediatrics 75:106-111

32. Monin P, Vert P 1987 The management of bronchopulmonary dysplasia. Clin Perinatol 14:531-549

33. Sinkin RA, Phelps DL 1987 New strategies for the prevention of bronchopulmonary dysplasia. Clin Perinatol 14:599-621 